\title{
Influence of Motivation, Internal Control Structure and Women Economic Empowerment on Poverty Reduction Implication on Improvement of Productivity
}

\author{
Nursito, Dewi Faeni
}

\begin{abstract}
Poverty is a global problem, often linked to needs, difficulties and shortcomings in many circumstances. Some people may understand this term subjective and comparative, while others see it in terms of moral and evaluative, and others understand it from a scientific point of view [1-4]. This poverty problem always accompanies the development process undertaken by each country. Poverty is a major problem facing developing countries including Indonesia. As a multi dimensional social phenomenon, poverty not only deals with economic dimensions but also deals with structural, psychological, cultural, ecological and other factors. The number of poor people is likely to increase, and it is undeniable that most victims of poverty are women and children [5-8]. There are still many women experiencing discrimination in various aspects of social, cultural as well as economic. Village women are particularly vulnerable Women need to be involved in planning, implementing activities, and evaluating and analyzing the impact of development. Nevertheless, the symptoms of poverty still show a real figure [6-10]. Regency, Subang, Indramayu and Cirebon are the North Coast Area of West Java where coastal areas tend to be higher poverty level [11-15].
\end{abstract}

\section{Introduction}

Poverty is a global problem, often linked to needs, difficulties and shortcomings in many circumstances. Some people may understand this term subjective and comparative, while others see it in terms of moral and evaluative, and others understand it from a scientific point of view [1-4]. This poverty problem always accompanies the development process undertaken by each country. Poverty is a major problem facing developing countries including Indonesia. As a multi dimensional social phenomenon, poverty not only deals with economic dimensions but also deals with structural, psychological, cultural, ecological and other factors. The number of poor people is likely to increase, and it is undeniable that most victims of poverty are women and children [5-8]. There are still many women experiencing discrimination in various aspects of social, cultural as well as economic. Village women are particularly vulnerable Women need to be involved in planning, implementing activities, and evaluating and analyzing the impact of

Revised Manuscript Received on July 05, 2019.

Nursito,

Faculty of Post Graduate, Universitas Budi Luhur nursito@budiluhur.ac.id development. Nevertheless, the symptoms of poverty still show a real figure [6-10]. Regency, Subang, Indramayu and Cirebon are the North Coast Area of West Java where coastal areas tend to be higher poverty level [11-15].

The women in the fishermen's area tend to be unproductive and especially when in tingga their husbands are working to sea that takes more than a month, to anticipate the level of poverty in the fishermen community required systematic motivation terstuktural and controlled so that empowerment of this woman will reduce the level of poverty in because women motivated will be more productive [16-22].

\subsection{Formulation of the problem}

1. Does motivation affect poverty alleviation

2. Does the internal control structure affect poverty alleviation

3. Does the economic empowerment of women affect poverty alleviation

4. Is the motivation, internal control structure, economic empowerment of women affect poverty alleviation simultaneously

5. Is the motivation, internal control structure, economic empowerment of women affects poverty alleviation simultaneously berimpikasi towards productivity

\section{Literature Study}

\subsection{Motivation}

Motivation is an instinctive drive both negative and constructive and destructive. " Siagian (2000: 143), According Simanjuntak (2000: 199) said that, Motivation in the framework of leadership is the process of how to grow and encourage someone to do or work. Moenir (2003: 130) motivation derived from within a person or motive has two elements. The first element is the impetus to act, the second element is the goal or goal (reward here can also be interpreted as a motivator) that will be directed by the action.

\subsection{Structure of Internal Control}

Organizational structure and all the means and the tools used to maintain the security of property belonging 
to the organization, giving accuracy and correctness of accounting data, promote efficiency in the operation and helps maintain compliance with the policy that has been in charge of management have first. (SAS: 55). The internal control structure should include the basis of policies and procedures designed and used to provide reasonable assurance. Moeller (2009: 33).

\subsection{Poverty Women in patriarchal culture}

According to UN data, 1/3 of the world's population live below the poverty line, while about $70 \%$ of them are women. Therefore it is necessary to do the right way to alleviate the poverty experienced by women. In Indonesia itself, there are various dimensions of poverty that affect women: due to weak bargaining power in society, repressive culture, poor due to disasters and conflicts, discrimination in public and domestic space, and ignorance of the state in issuing useful policies eradicate women in poverty. In fact, many discriminatory practices are perpetrated against women. (Henri 2002).

The source of the problem of poverty faced by women according to Muhadjir in Arjani (2007) lies in the patriarchal culture of living values in the community that position men as superior and subordinate women. This patriarchal culture is reflected in family, society, nation and state life and is a source of justification for the authority distribution system, decision-making system, work-sharing system, ownership system and gender-biased resourse distribution system. Such a culture will ultimately lead to discrimination, marginalization, exploitation and violence against women.

In the Javanese / Madura community that actually embraces the patrilineal kinship system, its patriarchal culture is still very strong. In a kinship system like this the value of boys is higher than that of girls. Children, because of their position as the successor of the family, they will feel superior and powerful. while women are in an inferior position. This will ultimately limit women's access to resources. Basically there are structural factors that cause individuals in the family and society to have no equal access to realize their rights as family members, members of society as well as citizens. One of the structural obstacles is the unjust and equal gender relations (gender relation) as a result of a highly paternalistic culture. In Balinese society, this condition is apparent because until now the limitations of women's access to education, economy, and others are still quite prominent. Various reasons can trigger the feminization of poverty that occurs in society, among others: the embedded of gender ideology that standardize the role of women in the domestic sector and men in the public sphere. This is what brings widespread impact on women's backwardness

\subsection{Mainstreaming, Equality, Gender Equity in Women's Economic Empowerment}

Discrimination against women in all its forms forms the basis for women's empowerment. It is undeniable that the impoverishment of women by patriarchal gender ideology positions women as unfortunate and often unfair members of society. Based on this, the main idea of women's empowerment leads from the concept of gender mainstreaming, gender equality, and justice. Mayoux (2005: 3 ) reveals that gender mainstreaming is as follows. "Mayans, 2005: 3) This is in line with the opinion of Sen (1999) which reveals that women as an agent of change has an important role in reducing poverty. Mayoux further discloses that gender equality is a condition in which women obtain equality and equal opportunity, and gender is no longer the basis of discrimination and injustice among the people.

\subsection{Elements of Women's Economic Empowerment}

In line with Kabeer (2001) in Mayoux, (2005a) states that there are five

the main elements that need to be considered in the process of empowering women, namely as follows.

\subsubsection{Welfare (Prosperity)}

This aspect can be said to be an important aspect in the effort to increase women empowerment. It can not be denied that in access to welfare, women occupy an unfavorable position. This welfare is divided into three main elements (Claros and Zahidi, 2005: 2-5). Women's economic participation is important not only to reduce the level of poverty in women, but also as an important step to increase household income and encourage economic development of the country as a whole. While educational attainment is the most fundamental aspect of women's empowerment activities, without obtaining adequate education, women are unable to access formal sector work, earn better wages, participate in government and achieve political influence. Health and wellbeing is a concept related to substantial differences between women and men in accessing adequate nutrition, health, reproductive facilities, and to express fundamental salvation and the integrity of a person. Amartya Sen (1999, in Claros and Zahidi, 2005) states that the education, employment and ownership of women's rights exert a strong influence on improving their ability to dominate their environment and contribute to economic development. Economic participation not only ceases to increase the number of working women, but also equality in the provision of wages.

\subsubsection{Access}

In Longwe language, access is defined as the ability of women to obtain rights / access to productive resources such as land, credit, training, marketing facilities, labor, and all public services equivalent to women. Access to technology and information is also another important aspect. Through technology and information, women can improve their economic and social productivity and influence the environment in which they live. Without access, understanding, and the ability to use information technology, poor women are far more marginalized from their communities, countries, and even the world.

\subsubsection{Consientisation}


Understanding the differences in gender roles and gender roles.

\subsubsection{Participation}

Equality of women's participation in decision-making, policy-making, planning and administration processes. This participation refers to equal representation of women in both voices in policy formulation affect their communities (Claros and Zahidi, 2005: 4). 5. Equality of Control (Equality in power).

Equality in power over factors of production, and distribution of benefits so that both women and men are in a dominant position. Here is a cycle that represents elements of women's empowerment.

\subsection{Micro Business}

\subsubsection{Definition of Micro Enterprises and Strengthening Efforts}

Business / program / project / activity / activity to strengthen micro business that can be realized invarious types of activities, among others: Capital, through the provision of credit, training, mentoring and facilitators, technical assistance and consultation, information and research provision

\subsubsection{Development of Micro Enterprises and Women Empowerment}

Micro-enterprises are classified as marginal enterprises, characterized by the use of relatively simple technology, low levels of capital and access to credit, and tend to be oriented toward local markets. In addition, micro business is also one of the main components of local economic development, and potentially improves the bargaining position of women in the family. (ADB Report). Micro and small business activities can not be separated from the role of women. Micro-enterprises are in great demand by women with the consideration that this effort can sustain household life and can meet the needs of self-development (Sumampouw, 2000). Although it is difficult to separate the roles of women and men in micro-enterprises, and there is no clear figure on the level of women's involvement in micro-enterprises, it is estimated that the portion is quite large and comparable to the share of women in small businesses, which is about $40 \%$.

\subsection{Poverty Alleviation}

Poverty alleviation itself can be interpreted as an effort to cut the chain of causes of poverty. (Soetomo, 2006) explains the factors of poverty such as physical weakness, isolation, vulnerability and helplessness. What factors must be prioritized or cutting the cause of poverty should start from where it depends on the condition of the community and the region concerned. Efforts to cut one of these links will be effective in the context of poverty alleviation if it has a chain impact on other factors related to the poverty network. In the case of directly addressed programs addressing poverty in the long term, it may not be effective if the program is not followed by social and political empowerment. (Hempri, 2013) formal and informal decision-making structures, and their

The mainstreaming of empowerment in the development of this society arises in view of the failure of past community development programs. Learning from past development, many development programs whose benefits can not be enjoyed by the people at the bottom layer. One reason is that the program is less relevant to the real problems and needs of the community. This is a logical consequence because in the formulation and determination of the program, the community at the lowest level is not included in the decision-making process, so that their aspirations, interests and needs are not accommodated in the program. This condition is a waste of energy and development resources in addition to the benefits of development to be not right on target because it can not be enjoyed by the layers of society that should be prioritized (Soetomo, 2011). Through the application of the principles of empowerment is well expected to poverty problems, backwardness and powerlessness of society can be overcome.

\subsection{Profitabilitas}

According to Harahap (2016: 304) profitability describes the ability of companies to earn profits through all the capabilities, and existing sources such as activities penjuala, cash, capital, the number of employees, the number of branches, and so on.

According Hermanto and Agung (2012: 102) "Profitability is a measure of the level of management effectiveness shown by the profit generated in sales and sales investment".

\subsection{Model Theory of Research Theory}

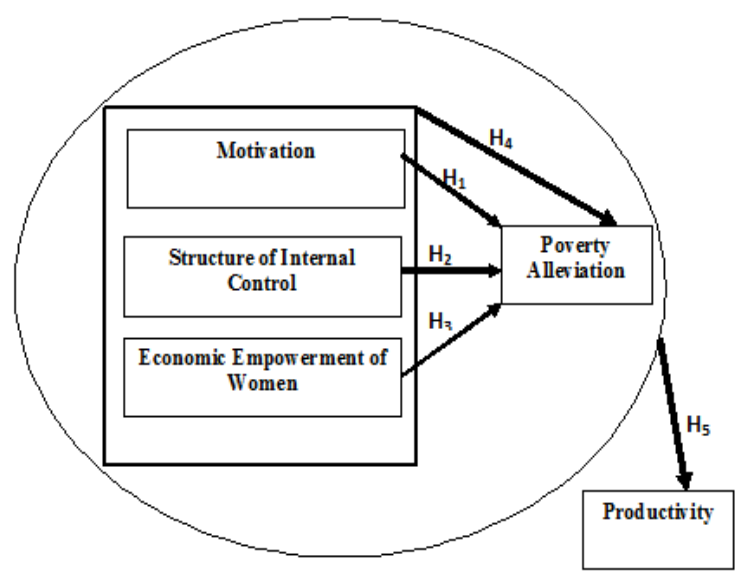

Figure 1. Theoretical Model of Research

Based on the above framework, the hypothesis can be determined:

There is a significant influence of motivation, internal control structure, economic empowerment of women affect poverty alleviation simultaneously berimpikasi on productivity in fishing communities in the district: Subang, Indramayu and Cirebon ". Data analysis method used in this research is by using Moderated Regression Analysis (MRA) or interaction test. To conduct an 
analysis with the regression model, data quality testing must be conducted

\section{DISCUSSION}

Testing of Moderated Regression Analysis (MRA)

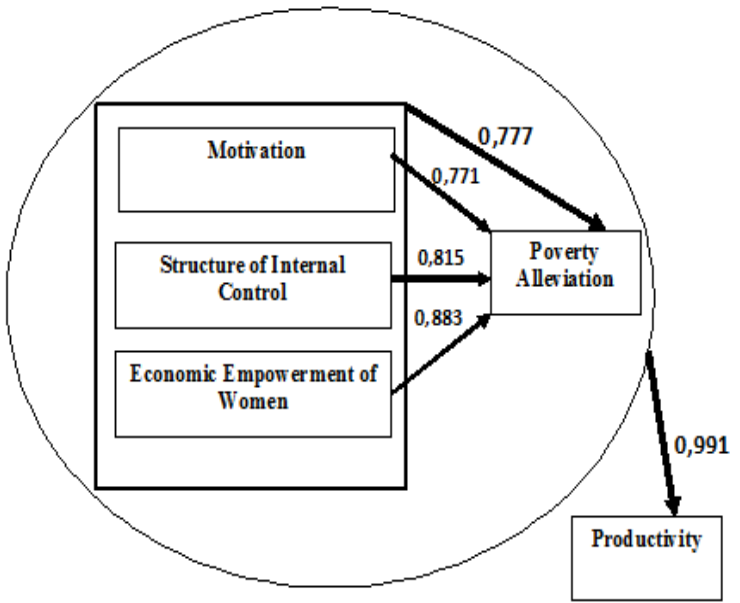

Figure 2. The Magnitude of Influence Value Moderated Regression Analysis (MRA)

\subsection{Analysis Results}

1. Motivation there is a significant influence on Poverty Alleviation.

Motivation has a positive and significant influence on Poverty Alleviation. Thus, the first hypothesis states that "Motivation positively affects Poverty Alleviation in fishing communities in three districts"

2. Internal Control Structure has a significant influence on Poverty Alleviation.

The Structure of Internal Control has a positive and significant influence on Poverty Alleviation. Thus, the first hypothesis stating that "Internal Control Structure positively affects Poverty Alleviation in fishing

3. Women's Economic Empowerment has a significant influence on Poverty Alleviation. first hypothesis stating that "Women's Economic Empowerment has a positive effect on Poverty Alleviation on fishing communities in three districts"

4. Motivation, Internal Control Structure and Women's Economic Empowerment have a significant influence on Poverty Alleviation simultaneously.

Motivation, Internal Control Structure and Women's Economic Empowerment affect Poverty Alleviation together. Based on hypothesis test results, the existence of Motivation, Internal Control Structure and Women's Economic Empowerment towards Poverty Alleviation significant influence ..

5. Motivation, Internal Control Structure and Economic Empowerment of Women there is a significant communities in three districts"

Women's Economic Empowerment has a positive and significant influence on Poverty Alleviation. Thus, the

influence on Poverty Alleviation has implications on Productivity.

Motivation, Internal Control Structure, Women's Economic Empowerment and Poverty Alleviation have a significant positive implication on Productivity Based on hypothesis test results, the existence of variables simultaneously has implications on productivity.

\section{CONCLUSION}

1. Motivation there is a significant influence on Poverty Alleviation.

With high motivation and jointly mobilized from various parties concerned with poverty alleviation, it will be better and faster the teralisasinya poverty alleviation fishermen community in three districts

2. Internal Control Structure has a significant influence on Poverty Alleviation.

Internal Control Structure has such an important role, it is based on the result of discussion if poverty eradication is done in a structured, systematic and controlled way, obstacles or obstacles will be solved well in alleviating the poverty of fishing communities in three districts.

3. Women's Economic Empowerment has a significant influence on Poverty Alleviation.

Women's economic empowerment has such an important role, indicating the increasing number of activities that are economically there will help the needs of the household and also will provide busy while waiting for the husband to work as a fisherman fishing in addition to taking care of children.

4. Motivation, Internal Control Structure and Women's Economic Empowerment have a significant influence on Poverty Alleviation Simultaneously.

With a high motivation to rise and move together in a structured and controlled manner, the economic empowerment of women affects Poverty Alleviation together in the fishing communities in three districts.

5. Motivation, Internal Control Structure and Economic Empowerment of Women there is a significant influence on Poverty Alleviation has implications on Productivity.

With a high motivation to rise and move together in a structured and controlled manner, in empowering women's economic empowerment in poverty alleviation together this has implications for the productivity of women fishermen in three districts

\subsection{Limitations}

1. This research is only conducted on fishermen communities in three districts on the north coast of West Java.

2. Variables and indicators used in this study are limited to three independent variables and one dependent variable to answer the existing problems. While the financial performance is still much to affect other than the variables studied, and would be better if 
complement and add other variables.

3. Financial report data is limited only from the empowerment of women so the results have not been maximized.
[13] Mayoux, Linda. (a). Gender Equity, Equality, and Women's Empowerment. Principle, Development and Framework. Aga Khan Foundation., 2001. Diakses dari situs http://www.genfinances.net

[14] Media Indonesia, 26 Mei 2003, Jakarta Post, 3 Juni 2003, Laporan ILO "Dimensi Gender dalam KrisisEkonomi", bekerja sama dengan Lembaga Demografi UI, Jakarta 2002

[15] Moeller Robert; Brink's Modern Internal Auditing. John Wiley and Sons. Inc. Hoboken, New Jersey Published Canada, 2009.

[16] Poerwandari, E. Kristi. Pendekatan Kualitatif Untuk Penelitian Perilaku Manusia. Perfecta. LPSP3Fakultas Psikologi Universitas Indonesia. Jakarta, 2005.

[17] Reeves, Hazel and Sally Baden. Gender and Development : Concept and Definition.

[18] Retno Endah Supeni dan Maheni Ika Sari 2011 Upaya Pemberdayaan Ekonomi Perempuan Melalui Pengembangan Manajemen Usaha Kecil Seminar Nasional Ilmu Ekonomi TerapanFakultas Ekonomi UNIMUS 2011

[19] Rosalia dkk. PEMBERDAYAAN PEREMPUAN DESA UNTUK MENGURANGI KEMISKINANSeminar Nasional Universitas PGRI Yogyakarta 2015

2. The next researcher should undertake similar research but with different sectors and with more samples so as to strengthen the results of previous studies.

Ethical clearance - Not required

Source of funding- Self

[20] Seminar Nasional Ilmu Ekonomi Terapan 110Fakultas Ekonomi UNIMUS 2011

[21] Sen, Amartya. Development as Freedom. New York. Anchor Books.1999

[22] www.mennegpp.go.id

\section{Conflict of Interest - Nil}

\section{References}

[1] ADB Report, Microenterprise Development: Not by Credit Alone http://www.adb.org/

[2] Documents/Books/Microenterprise/microenterp rise.pdf Empowering Women andCoping with Financial Crisis: An Exploratory Study of Zimbabwean Microenterprenuer http://www.usaidmicro.org/pdfs/aims/EmpoweringWomenpdf

[3] Arjani, Ni Luh. Feminisasi Kemiskinan dalam Kultur Patriarki. ejournal.unud.ac.id. Denpasar. 2007

[4] BPS, 2009

[5] BRIDGE DevelopmentGender Report No. 55. 2000 Claros, Augusto Lopez dan Saadia Zahidi. 2005. Woman Empowerment : Measuring The Global Gender Gap.Worl Economic Forum. Diakses dari situs : www.weforum.org

[6] Dreze, Jean dan Sen, Amartya. The Amartya Sen and Jean Drèze Omnibus:(comprising) Poverty and Famines;Hunger and Public Action; India: Economic Development and Social Opportunity. Oxford Universityn Press. 1999.

[7] Hastuti dan Akhmadi, "Kredit Kecil Perkotaan di Kabupaten Kulon Progo", Lembaga Penelitian SMERU, 2001

[8] Harahap, Sofyan Syafri; Teori Akuntansi. Rajawali Pers, 2016.

[9] Henry Sandee, Brahmantio Isdijoso, dan Sri Sulandjari, "SME clusters in Indonesia: An Analysis of GrowthDynamics and Employment Conditions", Report to the ILO, Jakarta, 2002http://kertyawitaradya.wordpress.com/2010/01/26/pemberday aan-usaha-uatutinjauan-

teoritis/http://store.jurnalperempuan.com/content/jurnal-

perempuan-edisi-42-mengurai- kemiskinanperempuan-di-mana

[10] Hudi Sartono, Sri Kusumastuti Rahayu, Bambang Soelaksono "Kredit Perdesaan di Kabupaten Cirebon, JawaBarat", Lembaga Penelitian SMERU, 2000

[11] Kabeer, Naila. Reflections on The Measurement of Women's Empowerment in Discussing Women Empowerment: Theory and Practices. Sida Studies No3 Journal. 2001

[12] Lembaga Demografi UI dan ILO Manila, "Dimensi Gender dalam Krisis Ekonomi”, Jakarta, 2002. 